Vol. 16 (2007): 177-187

\title{
Chromosome regions affecting body weight in egg layers
}

Mervi Honkatukia, Maria Tuiskula-Haavisto and Johanna Vilkki

MTT Agrifood Research Finland, Biotechnology and Food Research, Animal Genomics, FI-31600 Jokioinen, Finland, e-mail: mervi.honkatukia@mtt.fi

\begin{abstract}
We have previously mapped quantitative trait loci (QTL) affecting egg production and quality traits using a reciprocal cross of two divergent egg-layer lines. The lines differ also in body weight, and we initially identified genome-wide significant Mendelian QTL for adult body weight at 40 weeks of age and feed intake at 32-36 weeks of age. In addition, QTL with parent-of-origin effects were detected for feed intake and body weight. In the present study, a total of five body weight traits (weight at 16, 20, 24, 40 and 60 weeks of age) have been analysed in the same mapping population. New QTL affecting body weight at different ages were found on chromosomes 1, 4, 5, 6, and 13. Both Mendelian QTL and loci with parent-of-origin expression were found. Our findings are in good agreement with the results of previous studies on different mapping populations. The results elucidate the most important chromosome regions affecting weight in poultry in general and may add to the understanding of such loci among domestic animals.
\end{abstract}

Key-words: Egg laying chickens, QTL mapping, body weight

\section{Introduction}

A large number of studies have reported quantitative trait loci (QTL) for economically important traits in poultry. The majority of the studies (21 of 50 published ones) have dealt with growth-related traits (Abasht et al. 2006). This may reflect the straightforward accessibility of the phenotypes for several growth traits. The recently updated chick- en QTL database contains a total of 657 QTL from poultry, 345 of which are growth related (http:// www.animalgenome.org/QTLdb/chicken.html). The mapping population structures and results are thoroughly summarized in recent reviews by Abasht et al. (2006) and Hocking (2005). The general outline of the results regarding growth-related QTL is that there are numerous loci with moderate effects rather than a few QTL with a major effect. 
Honkatukia, M. et al. Chromosome regions affecting body weight in egg layers

The studies have mainly concentrated on the first weeks of growth (in broilers) and very few have included measurements of the whole growth period or adult weight.

Growth can be measured relative to body weight, feed efficiency or body composition. Successive measurements are forming a growth curve. At least three different stages can be distinguished from the growth curve. Early growth is due to rapid development of internal organs, such as the gastrointestinal tract, heart and liver (Lilja 1983). Most of the deposition of body mass takes place during the intermediate growth phase (between the age of 6-16 weeks). During the later period growth is more or less associated with deposition of fat (Jennen 2004). Individuals with high early growth rates have rapid development of the 'supply' organs, which are necessary to fulfil the nutritional demands of the growing animal (Blom and Lilja 2005). This process in turn promotes overall growth of the 'demand' organs (brain, muscles, skeleton and feathers) giving greater potential for growth. Weight gain is associated either with the above-mentioned developmental pattern or accumulation of abdominal fat. In broilers, long-term selection for fast growth and high yield has led to increased abdominal fat and feed intake (Wright et al. 2006).

In our previous analyses we have identified QTL mainly for egg production and egg quality traits (Tuiskula-Haavisto et al. 2002, TuiskulaHaavisto et al. 2004). Some of the QTL, especially those affecting adult body weight (at 40 weeks of age), feed intake, egg weight and sexual maturity were found to show parent-of origin effects, i.e. a specific QTL allele was expressed only when inherited through either parental germ line. In the present study, we investigated the role of Mendelian and parent-of-origin QTL affecting body weight throughout the life span (excluding early growth) in the same experimental population (TuiskulaHaavisto et al. 2002).

\section{Material and methods}

The mapping population is an $\mathrm{F}_{2}$ cross between two extreme egg layer lines: Rhode Island Red (RIR) and White Leghorn (WL). The RIR line is a typical brown egg layer with high feed intake and body weight. The WL line has been selected for several generations for high egg production and good feed efficiency. From each line two hens and two roosters were reciprocally crossed. From the $\mathrm{F}_{1}, 32$ hens and 8 roosters were crossed to produce a total of $305 \mathrm{~F}_{2}$ hens in three different hatches. All individuals of the $\mathrm{F}_{0}, \mathrm{~F}_{1}$ and $\mathrm{F}_{2}$ generations were genotyped and phenotypes were recorded on the $\mathrm{F}_{2}$ hens ( $\mathrm{Tu}-$ iskula-Haavisto et al. 2002). Compared to the previous study, new microsatellite markers were added to chromosomes 2, 4, 7, 8 and 10. The Haldane map length was $2344 \mathrm{cM}$. The full cross design and the linkage maps used for mapping are available at http://www.mtt.fi/julkaisut/chickenqtl/.

Table 1. Description of the traits analysed in the $\mathrm{F}_{2}$ generation from the reciprocal cross between Rhode Island Red and White Leghorn lines.

\begin{tabular}{lllllll}
\hline Body weight $(\mathrm{g})$ & Abbreviation & Minimum & Maximum & Mean & SD $^{1}$ & $\mathrm{n}^{2}$ \\
\cline { 2 - 5 } Age & & & & & & \\
16 weeks & BW16 & 800 & 1910 & 1402 & 181 & 303 \\
20 weeks & BW20 & 1226 & 2266 & 1635 & 198 & 303 \\
24 weeks & BW24 & 1240 & 2339 & 1690 & 209 & 299 \\
40 weeks* & BW40 & 1233 & 2782 & 1853 & 252 & 289 \\
60 weeks* & BW60 & 1202 & 2882 & 1922 & 273 & 282 \\
\hline
\end{tabular}

*Included in Tuiskula-Haavisto et al. 2002

${ }^{1}$ Standard deviation.

${ }^{2}$ Number of individuals. 
Vol. 16 (2007): 177-187

\section{Phenotypic measurements}

Body weight was measured at 16, 20, 24, 40, and at 60 weeks of age (BW16, BW20, BW24, BW40, $\mathrm{BW60)}$. The recorded traits are summarized in Table 1, including information on the variation in the $\mathrm{F}_{2}$ generation. BW40 and BW60 were included in the previous analyses (Tuiskula-Haavisto et al. 2002 and 2004), with slightly different marker maps.

\section{Systematic effects}

For part of the analyses, $\mathrm{F}_{2}$ records were pre-corrected for any significant effect of hatch number using least squares analysis (SAS proc GLM). The effect of hatch was significant for all the traits analysed in the present study.

\section{Genetic Models}

The $\mathrm{F}_{2}$ data were analysed following a line cross model (Haley et al. 1994) where for every $F_{2}$ individual the probabilities that it inherited two RIR alleles $\left(\mathrm{p}_{11}\right)$, two WL alleles $\left(\mathrm{p}_{22}\right)$, or one allele from each line $\left(\mathrm{p}_{12}\right.$ or $\mathrm{p}_{21}$; the first subscript indicating the paternally inherited, the second the maternally inherited allele) were inferred at $1 \mathrm{cM}$ intervals across the genome. At every position, the following Mendelian model was fitted:

$y_{j}=m+a p_{a j}+d p_{d j}+e_{j}$

where $y_{j}$ is the trait score of animal $j, m$ is the population mean, $a$ and $d$ are the estimated additive and dominance effects of a putative QTL at the given location, $\mathrm{p}_{a j}$ is the probability of animal $j$ to carry two RIR alleles, $p_{d j}$ the conditional probability of animal $j$ to be heterozygous, and $e_{j}$ is the residual error. An outbred line cross design provides the possibility to trace the parental origin of alleles in $F_{2}$ individuals back to $F_{1}$ parents. This enables analysis of potential parent-of-origin effects. Knott et al. (1998) introduced the contrast between hetero- zygous individuals with alternative parental origin as a test for parent-of-origin effects $\left(p_{i}=\mathrm{p}_{12}-\mathrm{p}_{21}\right)$ :

$y_{j}=m+a p_{a_{j}}+d p_{d_{j}}+i p_{i_{j}}+e_{j}$

Variables are as in [1]; with the extension that $i$ is the estimated imprinting effect. The model for parent-of-origin effects by Knott et al. (1998) was re-parameterised to enable a direct test for the contribution of the paternally and maternally inherited effect (De Koning et al. 2000). Model [2] can be re-written with a specific maternal and paternal QTL component:

$y_{j}=m+a_{p a t} p_{p a t}+a_{m a t} p_{m a t_{j}}+d p_{d_{j}}+e_{j}$

where $a_{p a t}$ is the paternally inherited QTL effect, $a_{\text {mat }}$ is the maternally inherited QTL effect, $\mathrm{p}_{\mathrm{pat}}$ $=\left[\mathrm{p}_{11}+\mathrm{p}_{12}\right]-\left[\mathrm{p}_{22}+\mathrm{p}_{21}\right]$ and $\mathrm{p}_{\mathrm{mat}}=\left[\mathrm{p}_{11}+\mathrm{p}_{21}\right]-\left[\mathrm{p}_{22}+\mathrm{p}_{12}\right]$. Models [2] and [3] are identical in terms of total variance explained by the model. This re-parameterisation allows additional models to be fitted with exclusive paternal or maternal expression:

$$
\begin{aligned}
& Y_{j}=m+a_{p a t} p_{p a t_{j}}+e_{j} \\
& Y j=m+a_{\text {mat }} p_{\text {mat }}+e_{j}
\end{aligned}
$$

\section{QTL Mapping}

We analysed thirteen autosomes and the sex chromosome Z, genotyped for a total of 114 microsatellite markers, for Mendelian and parent-of-origin specific QTL. Details on genotyping and linkage map construction were given by Tuiskula-Haavisto et al. (2002). Significance of the parent-of-origin effect was assessed using an F test of whether a full model explains significantly more variation than a Mendelian model. Subsequently, all autosomes were re-analysed using models with exclusive paternal or maternal expression. After derivation of the genetic model, the significance level, the QTL effects, and the confidence intervals were estimated using the inferred genetic model. 
Honkatukia, M. et al. Chromosome regions affecting body weight in egg layers

\section{Significance thresholds}

Significance thresholds for the presence of QTL against the $\mathrm{H}_{0}$ of no QTL were determined empirically for individual chromosomes by permutation (Churchill and Doerge 1994). The first level of significance was suggestive linkage where one false positive is expected in a genome scan (Lander and Kruglyak 1995). In order to claim significant linkage, we applied a 5\% genomewide significance level (Lander and Kruglyak 1995). To derive genome-wide significance levels from the chromosome-wide significance levels, we applied the following Bonferroni correction: $\mathrm{P}_{\text {genome-wide }}=1-\left(1-\mathrm{P}_{\text {chromosome-wise }}\right)^{1 / \mathrm{r}}$, where $\mathrm{r}$ is the relative contribution of the studied chromosome to the total genome length $(\mathrm{r}=$ chromosome length/ genome length).

The empirical genome-wide significance threshold for the presence of a QTL against the $\mathrm{H}_{0}$ of no QTL effect varied between 7.8 and 13.2 for the Mendelian QTL and 12.3 and 13.2 for analyses fitting only a single parental QTL effect. To facilitate graphical comparisons of different models, the negative logarithm of the comparison-wise $P$ values $\left[-\log _{10}\right.$ $(P)]$ of the F statistics is presented in the graphs (de Koning et al. 2002). The thresholds are averaged over all models that are represented in the graph.

Confidence intervals for QTL positions were obtained by bootstrapping. The sorted $\mathrm{F}$ ratios from the bootstrap replicates were used to determine the test statistic value corresponding to a desired (90\%) confidence interval (de Koning et al. 2000). The method used here allows for non-continuous confidence intervals and is close to the traditional LOD dropoff methods.

\section{Results}

Analysing 13 autosomes and the sex chromosome $\mathrm{Z}$ with a Mendelian model revealed a highly sig-

Table 2. Quantitative trait loci (QTL) affecting body weight detected by Mendelian inheritance model in the reciprocal $\mathrm{F}_{2}$ cross between Rhode Island Red and White Leghorn. Significant results are shown in bold.

\begin{tabular}{|c|c|c|c|c|c|c|c|c|c|}
\hline Trait $^{1}$ & $\mathrm{GGA}^{2}$ & $\mathrm{cM}^{3}$ & $\mathrm{CI} 90^{4}$ & F-ratio & $\begin{array}{l}\text { Genome- } \\
\text { wide P }\end{array}$ & $\begin{array}{c}\text { Chromosome- } \\
\text { wise P }\end{array}$ & $\begin{array}{c}\text { Additive }^{5} \\
\text { effect } \pm \mathrm{SE}\end{array}$ & $\begin{array}{l}\text { Dominance }^{6} \\
\text { effect } \pm \mathrm{SE}\end{array}$ & $\mathrm{R}^{2}$ \\
\hline BW20 & 1 & 291 & $279-304$ & 7.72 & 0.057 & 0.015 & $-45.2 \pm 20.9$ & $129.2 \pm 41.0$ & 4.8 \\
\hline BW60 & 1 & 297 & 291-303 & 7.75 & 0.053 & 0.014 & $-44.9 \pm 28.4$ & $180.0 \pm 51.0$ & 5.2 \\
\hline BW16 & 4 & 195 & $189-204$ & 58.72 & $<0.0009$ & $<0.0001$ & $+127.5 \pm 11.8$ & $-7.4 \pm 18.0$ & 28.0 \\
\hline BW20 & 4 & 196 & 189-204 & 68.10 & $<0.0009$ & $<0.0001$ & $+163.6 \pm 14.1$ & $-20.2 \pm 21.7$ & 31.2 \\
\hline BW24 & 4 & 196 & $187-206$ & 48.49 & $<0.0009$ & $<0.0001$ & $+154.1 \pm 15.7$ & $-8.5 \pm 23.9$ & 24.7 \\
\hline BW40 & 4 & 195 & $179-231$ & 51.10 & $<0.0009$ & $<0.0001$ & $+190.2 \pm 18.9$ & $-19.6 \pm 28.5$ & 26.3 \\
\hline BW60 & 4 & 198 & 189-209 & 33.60 & $<0.0009$ & $<0.0001$ & $+189.2 \pm 23.3$ & $-34.0 \pm 35.7$ & 19.4 \\
\hline BW16 & 6 & 37 & $15-56$ & 5.81 & 0.39 & 0.015 & $+33.4 \pm 14.1$ & $-48.2 \pm 19.2$ & 3.7 \\
\hline BW20 & 6 & 39 & $3-53$ & 7.14 & 0.16 & 0.0054 & $+52.9 \pm 17.5$ & $-57.2 \pm 24.7$ & 4.5 \\
\hline BW24 & 6 & 36 & $13-49$ & 5.97 & 0.34 & 0.013 & $+30.8 \pm 17.5$ & $-70.8 \pm 23.1$ & 3.8 \\
\hline
\end{tabular}

${ }^{1}$ Trait definitions are given in Table $1 .{ }^{2}$ Chicken chromosome (Gallus gallus). ${ }^{3}$ The most likely position of the QTL, at centiMorgan (cM). ${ }^{4} 90 \%$ confidence interval for the QTL position. ${ }^{5}$ Additive QTL effect reported for the Rhode Island Red QTL allele is half of the average phenotypic difference between animals carrying two Rhode Island Red alleles and those carrying two White Leghorn alleles; estimates are given with standard errors (SE).

${ }^{6}$ The dominance effect is the deviation of the phenotypes of the heterozygous birds from the mean of the groups of homozygous birds; estimates are given with standard errors. $\mathrm{R}^{2}$ refers to the proportion (\%) of phenotypic variance explained by the QTL. 


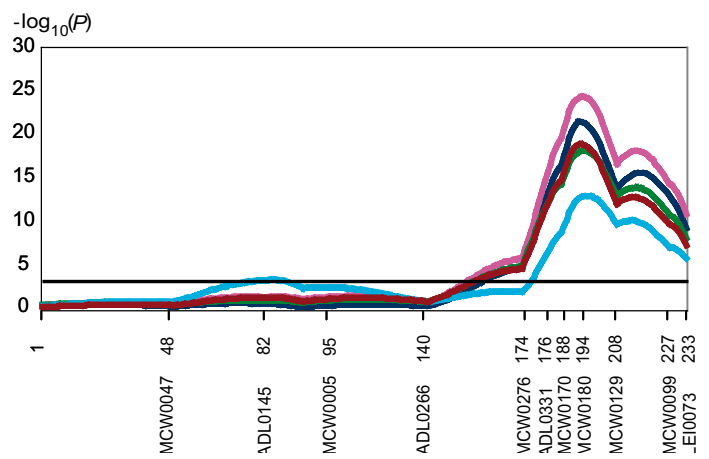

Fig. 1 Test statistic profiles for Mendelian quantitative trait loci on chicken chromosome 4 affecting body weight at:
16 weeks
24 weeks $\square, 40$ weeks $\square$, and
60 weeks of age.

The black solid horizontal line denotes the 5\% genomewise significance threshold for the Mendelian model. The marker names and locations are indicated on the $\mathrm{X}$-axis.

nificant QTL region $\left(\mathrm{P}_{\text {genome-wide }}<0.0009\right)$ affecting all body weight measurements (BW16, BW20, BW24, BW40, BW60) on GGA4 (Gallus gallus chromosome 4) (Fig. 1), two suggestive QTL ( $P_{\mathrm{g}}$ enome-wide $=0.053$ and 0.057 ) for BW20 and BW60 on GGA1 and three suggestive QTL (at $1 \%$ chromosome-wise significance level) for BW16, BW20 and BW24 on GGA6 (Table 2).

At the chromosome region with genome-wide significant Mendelian QTL effected on all body weight measurements on chromosome 4 , a single individual QTL explained $19.4-31.2 \%$ of the total phenotypic variance with the additive effect ranging from 0.7 to 1.05 standard deviation of the F2 (Table 2). The RIR allele effect for all these QTL was positive. The confidence intervals for all QTL were within the marker bracket ADL0331LEI0073 (179-231 cM) and the highest F-ratio for all body weight measurements occurred of positions between 195 and $200 \mathrm{cM}$ close to marker MCW0180 (Fig. 1). This area was already detected in our previous study to affect BW40, egg weight and feed intake. Other research groups have also detected growth related QTL at this particular region on GGA4. Jacobsson et al. (2005) and Sewalem et al. (2002) have observed body weight

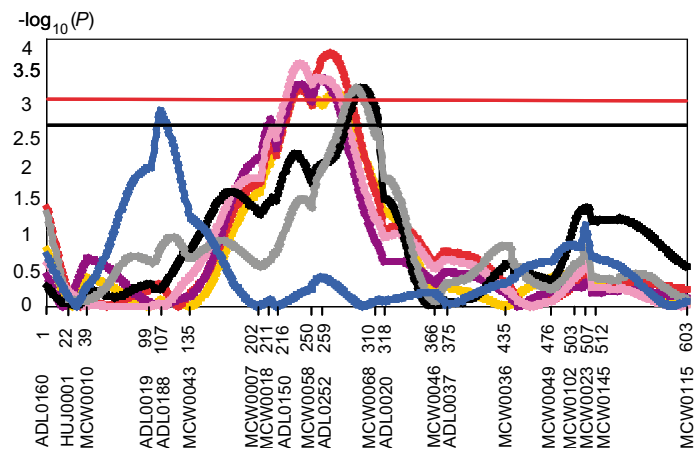

Fig. 2. Test statistic profiles for quantitative trait loci (QTL) on chicken chromosome 1. Mendelian QTL were found for body weight at

20 weeks of age and at 60 weeks of age.

Maternally expressed QTL were found for body weight at 16 weeks of age , 20 weeks of age , 24 weeks of age , and 40 weeks of age , and paternally expressed QTL for body weight at 20 weeks of age . The black solid horizontal line denotes the $5 \%$ chromosome-wise significance threshold for the Mendelian model and the red solid horizontal line denotes the $5 \%$ genome-wise significance threshold for the model including uniparental effects. The marker names and locations are indicated on the $\mathrm{X}$-axis.

QTL at 187-217 cM, and 138-243 cM, respectively. Park et al. (2006) detected breast muscle QTL at 187-217 cM and McElroy et al. (2006) a QTL affecting abdominal fat (153-201 cM). Carcass weight QTL of Ikeobi et al. (2002) located at a wider area (138-243 cM).

The suggestive Mendelian QTL region on GGA1 affecting both BW20 and BW60 lay between 279 and $304 \mathrm{cM}$. The F-ratio curves for BW20 and BW60 had almost overlapping confidence intervals (Fig. 2, Table 2). The dominance effects were remarkably high for both the traits. BW20 was not detected in the previous scan, where body weight was analysed only at 40 and 60 weeks of age. Moreover, a maternally expressed QTL for feed intake was identified in our previous study in this region. Hansen et al. (2005) have detected a Mendelian QTL for feed intake in the same region.

In addition, a suggestive Mendelian QTL region was found on GGA6 affecting body weight 
Honkatukia, M. et al. Chromosome regions affecting body weight in egg layers

at 16, 20 and 24 weeks of age. The highest test statistic for each QTL effect lay within three centimorgans $(36-39 \mathrm{cM})$, at or close to the marker ADL0040 (at $64 \mathrm{cM}$ in the 2005 consensus map). The RIR allele effects were dominant and negative. Results of three other research groups (Sewalem et al. 2002, Siwek et al. 2004, Zhou et al. 2006a) are supporting the presence of QTL affecting juvenile body weight or weight gain at this particular position.

Searching the 13 autosomes using models with uniparental expression revealed three new genomewide significant QTL $\left(\mathrm{P}_{\text {genome-wide }}=0.046\right.$ to 0.014$)$ and one suggestive $\mathrm{QTL}\left(\mathrm{P}_{\text {chromosome-wise }}=0.026\right)$ on chromosome 1 (GGA1) and one suggestive QTL $\left(\mathrm{P}_{\text {chromosome-wise }}=0.044\right)$ on chromosome 5 as well as three suggestive QTL on GGA13 (Table 3).

The locations of body weight QTL with mater- nal expression on GGA1 for BW16, BW20, BW24 co-located with the QTL for BW40 observed previously (Tuiskula-Haavisto et al. 2004). The confidence intervals for BW16, BW20, BW24, and BW40 were overlapping and the highest test statistics lay between 239 and $267 \mathrm{cM}$ in each case. These individual QTL explain from 3.4 to $4.6 \%$ of the phenotypic variance and the RIR allele effect was negative at all loci varying from $-40.12 \mathrm{~g}$ to $-66.5 \mathrm{~g}$. A suggestive QTL with paternal expression for BW20 was located on GGA1 at $107 \mathrm{cM}$ (Fig. 2). The effect of the RIR allele at this QTL was also negative (-37.55g) (Table 3).

The suggestive QTL on chromosome 5 (GGA5) showed maternal expression for BW16. The RIR allele effect was negative ( $-26 \mathrm{~g})$. The highest F-ratio was located at the marker ADL0233. The suggestive QTL with paternal expression for BW24, BW40 and

Table 3. Quantitative trait loci (QTL) affecting body weight showing significant parent-of-origin specific effects in the reciprocal F2 cross between Rhode Island Red and White Leghorn. Uniparentally expressed QTL that are significantly supported by comparison of the full model against a Mendelian model are shown. F ratios for the individual components of the model (maternal effect, paternal effect, dominance) at the most likely position of the QTL are shown. The F ratio for the inferred genetic model is shown in bold.

\begin{tabular}{|c|c|c|c|c|c|c|c|c|c|c|c|}
\hline \multirow[b]{2}{*}{ Trait $^{1}$} & \multirow[b]{2}{*}{ GGA } & \multirow[b]{2}{*}{$\mathrm{cM}^{2}$} & \multirow[b]{2}{*}{$\mathrm{CI} 90^{3}$} & \multicolumn{4}{|c|}{ F-ratio } & \multirow[b]{2}{*}{$\begin{array}{l}\text { Genome- } \\
\text { wide }{ }^{4} \mathrm{P}\end{array}$} & \multirow[b]{2}{*}{$\begin{array}{l}\text { Chromo- } \\
\text { some } \\
\text { wide }^{5} \mathrm{P}\end{array}$} & \multirow[b]{2}{*}{ QTL effect ${ }^{6}$} & \multirow[b]{2}{*}{$\mathrm{R}^{2}$} \\
\hline & & & & $\begin{array}{l}\text { Imprint vs } \\
\text { Mendelian }\end{array}$ & Maternal & Paternal & Dominance & & & & \\
\hline BW20 & 1 & 107 & $84-126$ & $8.04 * *$ & 0.54 & 10.72 & 0.89 & 0.089 & 0.026 & $-37.55 \pm 11.5$ & 3.4 \\
\hline BW16 & 1 & 239 & 218-296 & $7.74 * *$ & 12.26 & 0.07 & 0.09 & 0.046 & 0.013 & $-40.12 \pm 11.2$ & 3.9 \\
\hline BW20 & 1 & 267 & $279-304$ & $4.68 *$ & 14.55 & 0.67 & 0.96 & 0.014 & 0.004 & $-56.74 \pm 14.8$ & 4.6 \\
\hline BW24 & 1 & 259 & $203-216$ & $3.85 *$ & 12.94 & 1.19 & 0.004 & 0.014 & 0.004 & $-50.36 \pm 14.0$ & 4.1 \\
\hline BW40 & 1 & 239 & $212-285$ & $6.3^{*}$ & 13.87 & 2.33 & 0.02 & 0.018 & 0.005 & $-66.54 \pm 17.8$ & 4.6 \\
\hline BW16 & 5 & 117 & $107-122$ & $5.67 *$ & 7.64 & 0.48 & 1.4 & 0.55 & 0.044 & $-26.04 \pm 9.4$ & 2.4 \\
\hline BW24 & 13 & 32 & $5-32$ & $5.17 *$ & 0.32 & 6.47 & 0.11 & 0.78 & 0.022 & $-35.18 \pm 13.8$ & 2.1 \\
\hline BW40 & 13 & 32 & $5-32$ & $4.47^{*}$ & 0.92 & 7.18 & 0.11 & 0.64 & 0.015 & $-45.76 \pm 17.1$ & 2.4 \\
\hline BW60 & 13 & 32 & $12-32$ & $6.77 *$ & 0.03 & 5.96 & 0.54 & 0.85 & 0.028 & $-47.11 \pm 19.2$ & 2.0 \\
\hline
\end{tabular}

${ }^{1}$ Trait definitions are given in Table 1.

2 The most likely position of the QTL.

${ }^{3} 90 \%$ confidence interval for the QTL position.

${ }^{4}$ Genome-wide significance for the QTL under the inferred genetic model.

${ }^{5}$ Chromosome-wise significance for the QTL under the inferred genetic model.

${ }^{6}$ The deviation of the Rhode Island Red (RIR) allele from the White Leghorn (WL) allele under the inferred genetic model (maternal or paternal expression).

$* \mathrm{P} \leq 0.05, * * \mathrm{P} \leq 0.01$. 
Vol. 16 (2007): 177-187

BW60 found on chromosome 13 all have the highest test statistics at the same point at $32 \mathrm{cM}$, at the marker MCW0104 (Table 3), and at all loci the RIR allele effect was negative. The suggestive paternally expressed BW60 QTL was already detected in the earlier scan (Tuiskula-Haavisto et al. 2004), but it was not reported as only genome-wide significant results were then included.

\section{Discussion}

Our results give support to earlier findings on both Mendelian and parent-of-origin expressed QTL. The Mendelian QTL were found within areas, where many previous studies have shown QTL for growth related traits. At present it is impossible to estimate if similar results from different studies reflect the effects of same loci or regions with many QTL affecting these traits. Likewise, it is not possible to estimate even for our own experiment how many different genes may be involved in the effects at each region or, in other words, how many of the QTL effects are due to pleiotropic effects of one gene or due to linked genes. Some tentative conclusions might be made based on the observed effects. For example, in the present study the QTL region on GGA4 has effects on body weight at all measured ages. In all cases the RIR allele effect is positive and of approximately the same size. It could be concluded that these are all effects of the same locus, which is active throughout the life span. One of the potential candidate genes to permanently affect body weight in the region between markers MCW0276 and MCW0129 is PPARGC1A (NP_001006457.1) (also known as PGC-1 $\alpha$ ), a key regulator of energy metabolism (Liang and Ward 2006). It is involved in regulating energy homeostasis, thermal regulation, and glucose metabolism in the liver, fat and muscle tissues (Wu et al. 2006). In fact, Wu et al. (2006) have detected association between an amino acid substitution (Asp216Asn) of PPARGC1A and $\mathrm{BW}$ at 4 weeks and abdominal fat weight in different chicken populations like White Plymouth Rock and White Leghorn.
On the other hand, at the QTL region on chromosome 6 the RIR allele effect on growth is similar for all three QTL found to affect the early measuring periods (16, 20 and 24 weeks of age). No QTL for later weight measurements, the other production traits or feed intake have been detected on this chromosome in any earlier studies (e.g. TuiskulaHaavisto et al. 2002 and 2004). This might suggest the action of a single locus that is active only during the early or intermediate stages of growth (a possible maturity QTL), and is not involved in the later growth related to energy balance (fat deposition).

The recent findings of QTL with parent-of-origin specific effects in the chicken may provide one more explanation for the well-known reciprocal effects in poultry, hypothesized to originate from sexlinked genes or maternal effects. Our initial findings of QTL with parent-of-origin effects (Tuiskula-Haavisto et al. 2004) suggested that the phenomenon deserves closer scrutiny. Parent-of-origin effects have thereafter been reported for growth and carcass traits in chicken (McElroy et al. 2006) and for QTL for body weight and feed intake in Japanese quail (Minvielle et al. 2005).

The best-known epigenetic phenomenon leading to parent-of-origin-specific expression in mammals is genomic imprinting. Recent comparative mapping has provided evidence for the conservation of orthologous imprinted gene clusters on chicken chromosomes (Dunzinger et al. 2005). Furthermore, some of these genes exhibit asynchronous DNA replication, an epigenetic mark specific for all imprinted regions. Many of the mapped parent-of-origin specific QTL effects in poultry locate in or close to these conserved regions that show some of the basic features involved in monoallelic expression and thus raise a need to review the possible involvement of imprinting in parent-oforigin / reciprocal effects in poultry. A majority of the imprinted genes in mammals regulate embryonic growth in all vertebrates. Although the possible imprinting-like effects in birds may involve different mechanisms or genes than in mammals, the growth-related QTL with parent-of-origin effects are prime candidates to study the phenomenon in chicken. 


\section{AGRICULTURAL AND FOOD SCIENCE}

Honkatukia, M. et al. Chromosome regions affecting body weight in egg layers

In the following we discuss our new results on body weight QTL with parent-of-origin effects, with special emphasis on the co-location of the observed parent-of-origin effects, clustering of chicken orthologues of mammalian imprinted genes and asynchronously replicating regions in chicken. The QTL database (http://www.animalgenome.org/QTLdb/chicken.html) indicates several discrete QTL areas affecting weight related traits across the chicken chromosome 1 . In the present study we found evidence for the existence of two independent growth related QTL regions. The first QTL region is found within the marker bracket MCW0007-MCW0068 (202-310 cM on our linkage map and $215 \mathrm{cM}-283 \mathrm{cM}$ on the 2005 consensus map (http://www.thearkdb.org). This area includes QTL with both Mendelian and parent-of-origin effects. The QTL with maternal expression for body weight at 16,20 , and 24 weeks of age are located within the same chromosome area as the maternally expressed QTL affecting body weight at 40 weeks of age in our earlier scan (Tuiskula-Haavisto et al. 2004). Studies by McElroy et al. (2006), van Kaam et al. (1999) and Sewalem et al. (2002) also support existence of Mendelian QTL affecting body weight at this location. Mendelian QTL have also been found in this area (between markers LEI0174 and LEI0171) for body weight at 13 and 16 weeks of age in a $F_{2}$ cross between two genetically different lines (slow growing native breed and heavy weight broiler) (Tatsuda and Fujinaka 2001). Jennen et al. (2004) found Mendelian QTL on the same chromosome area (between markers MCW0058 and MCW0101) affecting percentage of abdominal fat at 10 weeks of age in a cross between two broiler dam lines. In a further study on the generation 9 of the same population, QTL were found for body weight at 5 and 7 weeks of age (Jennen et al. 2005) between markers MCW0018 and MCW0058.

The other region in this study affecting growth traits on chromosome 1 is flanked by markers MCW0010 and MCW0043 (at $39 \mathrm{cM}$ and $135 \mathrm{cM}$ on our linkage map and $71 \mathrm{cM}$ and $156 \mathrm{cM}$ on the consensus linkage map). The suggestive paternally expressed QTL found in this region has an effect on body weight at the age of 20 weeks. Five other re- search groups have found Mendelian QTL affecting body weight in the same area around 80-160 cM (Tatsuda and Fujinaka 2001, Ikeobi et al. 2002, Sewalem et al. 2002, Kerje et al. 2003, Zhou et al. 2006b). Of these studies, Sewalem et al. (2002) and Ikeobi et al. (2002) analysed possibile parent-of-origin effects without finding any support for them. In the rest of the studies possible parent-of-origin effects were not considered, and therefore the exact nature of these QTL remains to be analysed. In addition, QTL affecting the weight of heart and leg muscle (drumstick) have been found at positions of 72-109 cM and 122-125 cM (Navarro et al. 2005, Zhou et al. 2006b).

The human Prader-Willi/Angelman syndrome imprinted gene cluster (Nicholls and Knepper 2001 ) is to some extent conserved on chicken chromosome 1 in two different areas; the MKRN3 gene at $58.8 \mathrm{Mb}$ corresponding to a linkage map location between markers ADL0188 and MCW0007 and gene cluster Gabrg3, Gabra5, Gabrb3, Atp10a and Ube $3 a$ at $135.0-136.0 \mathrm{Mb}$, corresponding to position around $400 \mathrm{cM}$ in our linkage map. The MKRN3 region locates between the two QTL regions with parent-of-origin effects found in this study.

On chromosome 5 we detected a suggestive QTL with maternal expression affecting BW16 at marker position ADL0233 (155 cM on the consensus 2005 map). This corresponds to the genomic region around $51.4 \mathrm{Mb}$ (http://www.ensembl.org/ Gallus_gallus/index.html, assembly WASHUC2) harbouring the asynchronously replicating mammalian imprinted gene orthologues DLK1 (deltalike homolog 1 , cell surface transmembrane glycoprotein) and DIO3 (type 3 deiodinase, thyroid hormone inactivating enzyme) (Dunzinger et al. 2005). These genes could be studied for mono-allelic expression as candidates for the parent-of-origin effect. Zhou et al. (2006a) found a Mendelian QTL for body weight partly overlapping with our result. They have also detected leg muscle (drumstick) and liver weight QTL at the same location.

Jacobsson et al. (2005), Sewalem et al. (2002) and Jennen et al. (2004) have found QTL affecting early body weight in the same area on GGA13 that was identified in this study to harbour paternal- 
Vol. 16 (2007): 177-187

ly expressed QTL for body weight. QTL affecting muscle growth (drumstick, heart, thigh) have been found within the same area (Ikeobi et al. 2002, Navarro et al. 2005). No imprinted gene orthologues or asynchronously replicating genes have been found on this chromosome.

In conclusion, our QTL findings are in good agreement with the results of previous studies from different mapping populations, confirming especially the important and common QTL regions on chromosomes 1 and 4. These findings suggest that these regions include very important growth genes that may show pure Mendelian inheritance (chromosome 4) or both Mendelian inheritance and parent-of-origin expression. The fact that these regions are repeatedly detected as major QTL in various types of populations/crosses indicates that polymorphism is retained at these loci for some reason across poultry species and breeds.

The results elucidate the most important chromosome regions affecting growth and fat deposition in poultry in general and may add to the understanding of such loci among domestic animals. Our results underline the possible involvement of parent-of-origin effects in the reciprocal differences in hybrid performance and give ground for further studies on imprinting-like mechanisms in poultry in specific QTL regions.

\section{References}

Abasht, B., Dekkers, J.C. \& Lamont, S.J. 2006. Review of quantitative trait loci identified in the chicken. Poultry Science 85: 2079-2096.

Blom, J. \& Lilja, C. 2005. A comparative study of embryonic development of some bird species with different patterns of postnatal growth. Zoology (Jena, Germany) 108: 81-95.

Churchill, G.A. \& Doerge, R.W. 1994. Empirical threshold values for quantitative trait mapping. Genetics 138: 963-971.

de Koning, D.J., Bovenhuis, H. \& van Arendonk, J.A. 2002. On the detection of imprinted quantitative trait loci in experimental crosses of outbred species. Genetics 161: 931-938.

de Koning, D.J., Rattink, A.P., Harlizius, B., van Arendonk, J.A., Brascamp, E.W. \& Groenen, M.A. 2000. Genome-wide scan for body composition in pigs reveals important role of imprinting. Proceedings of the National Academy of Sciences of the United States of America 97: 7947-7950.

Dunzinger, U., Nanda, I., Schmid, M., Haaf, T. \& Zechner, U. 2005. Chicken orthologues of mammalian imprinted genes are clustered on macrochromosomes and replicate asynchronously. Trends in Genetics : TIG 21: 488-492.

Haley, C.S., Knott, S.A. \& Elsen, J.M. 1994. Mapping quantitative trait loci in crosses between outbred lines using least squares. Genetics 136: 1195-1207.

Hansen, C., Yi, N., Zhang, Y.M., Xu, S., Gavora, J. \& Cheng, H.H. 2005. Identification of QTL for production traits in chickens. Animal Biotechnology 16: 67-79.

Hocking, P.M. 2005. Review on QTL mapping results in chickens. World's Poultry Science Journal 61: 215226.

Ikeobi, C.O., Woolliams, J.A., Morrice, D.R., Law, A., Windsor, D., Burt, D.W. \& Hocking, P.M. 2002. Quantitative trait loci affecting fatness in the chicken. Animal Genetics 33: 428-435.

Jacobsson, L., Park, H.B., Wahlberg, P., Fredriksson, R., Perez-Enciso, M., Siegel, P.B. \& Andersson, L. 2005. Many QTLs with minor additive effects are associated with a large difference in growth between two selection lines in chickens. Genetical Research 86: 115-125.

Jennen, D.G., Vereijken, A.L., Bovenhuis, H., Crooijmans, R.M., van der Poel, J.J. \& Groenen, M.A. 2005. Confirmation of quantitative trait loci affecting fatness in chickens. Genetics, Selection, Evolution.: GSE 37: 215-228.

Jennen, D.G., Vereijken, A.L., Bovenhuis, H., Crooijmans, R.P., Veenendaal, A., van der Poel, J.J. \& Groenen, M.A. 2004. Detection and localization of quantitative trait loci affecting fatness in broilers. Poultry Science 83: 295-301.

Jennen, D.G.J. 2004. Chicken fatness: From QTL to candidate gene. Thesis Wageningen University, The Netherlands. $176 \mathrm{p}$.

Kerje, S., Carlborg, O., Jacobsson, L., Schutz, K., Hartmann, C., Jensen, P. \& Andersson, L. 2003. The twofold difference in adult size between the red junglefowl and White Leghorn chickens is largely explained by a limited number of QTLs. Animal Genetics 34: 264-274.

Knott, S.A., Marklund, L., Haley, C.S., Andersson, K., William, D., Ellegren, H., Fredholm, M., Hansson, I., Hoyheim, B., Lundström, K., Moller, M., \& Andersson, L. 1998. Multiple marker mapping of quantitative trait loci in a cross between outbred Wild Boar and Large White pigs. Genetics 149: 1069-1080.

Lander, E. \& Kruglyak, L. 1995. Genetic dissection of complex traits: guidelines for interpreting and reporting linkage results. Nature Genetics 11: 241-247.

Liang, H. \& Ward, W.F. 2006. PGC-1alpha: a key regulator of energy metabolism. Advances in Physiology Education 30: 145-151.

Lilja, C. 1983. A comparative study of postnatal growth and organ development in some species of birds. Growth 47: 317-339.

McElroy, J.P., Kim, J.J., Harry, D.E., Brown, S.R., Dekkers, J.C. \& Lamont, S.J. 2006. Identification of trait loci affecting white meat percentage and other growth and carcass traits in commercial broiler chickens. Poultry 


\section{AGRICULTURAL AND FOOD SCIENCE}

Honkatukia, M. et al. Chromosome regions affecting body weight in egg layers

Science 85: 593-605.

Minvielle, F., Kayang, B.B., Inoue-Murayama, M., Miwa, M., Vignal, A., Gourichon, D., Neau, A., Monvoisin, J.L. \& Ito, S. 2005. Microsatellite mapping of QTL affecting growth, feed consumption, egg production, tonic immobility and body temperature of Japanese quail. BMC Genomics 6: 87.

Navarro, P., Visscher, P.M., Knott, S.A., Burt, D.W., Hocking, P.M. \& Haley, C.S. 2005. Mapping of quantitative trait loci affecting organ weights and blood variables in a broiler layer cross. British Poultry Science 46: 430-442.

Nicholls, R.D. \& Knepper, J.L. 2001. Genome organization, function, and imprinting in Prader-Willi and Angelman syndromes. Annual Review of Genomics and Human Genetics 2: 153-175.

Park, H.B., Jacobsson, L., Wahlberg, P., Siegel, P.B. \& Andersson, L. 2006. QTL analysis of body composition and metabolic traits in an intercross between chicken lines divergently selected for growth. Physiological Genomics 25: 216-223.

Sewalem, A., Morrice, D.M., Law, A., Windsor, D., Haley, C.S., Ikeobi, C.O., Burt, D.W. \& Hocking, P.M. 2002. Mapping of quantitative trait loci for body weight at three, six, and nine weeks of age in a broiler layer cross. Poultry Science 81: 1775-1781.

Siwek, M., Cornelissen, S.J., Buitenhuis, A.J., Nieuwland, M.G., Bovenhuis, H., Crooijmans, R.P., Groenen, M.A., Parmentier, H.K. \& van der Poel, J.J. 2004. Quantitative trait loci for body weight in layers differ from quantitative trait loci specific for antibody responses to sheep red blood cells. Poultry Science 83: 853-859.

Tatsuda, K. \& Fujinaka, K. 2001. Genetic mapping of the
QTL affecting body weight in chickens using a F2 family. British Poultry Science 42: 333-337.

Tuiskula-Haavisto, M., de Koning, D.J., Honkatukia, M., Schulman, N.F., Mäki-Tanila, A. \& Vilkki, J. 2004. Quantitative trait loci with parent-of-origin effects in chicken. Genetical Research 84: 57-66.

Tuiskula-Haavisto, M., Honkatukia, M., Vilkki, J., de Koning, D.J., Schulman, N.F. \& Maki-Tanila, A. 2002. Mapping of quantitative trait loci affecting quality and production traits in egg layers. Poultry Science 81: 919-927.

van Kaam, J.B., Groenen, M.A., Bovenhuis, H., Veenendaal, A., Vereijken, A.L. \& van Arendonk, J.A. 1999. Whole genome scan in chickens for quantitative trait loci affecting growth and feed efficiency. Poultry Science 78: 15-23.

Wright, D., Kerje, S., Lundstrom, K., Babol, J., Schutz, K., Jensen, P. \& Andersson, L. 2006. Quantitative trait loci analysis of egg and meat production traits in a red junglefowl $x$ White Leghorn cross. Animal Genetics 37: 529-534.

Wu, G.Q., Deng, X.M., Li, J.Y., Li, N. \& Yang, N. 2006. A potential molecular marker for selection against abdominal fatness in chickens. Poultry Science 85: 1896-1899.

Zhou, H., Deeb, N., Evock-Clover, C.M., Ashwell, C.M. \& Lamont, S.J. 2006a. Genome-wide linkage analysis to identify chromosomal regions affecting phenotypic traits in the chicken. I. Growth and average daily gain. Poultry Science 85: 1700-1711.

Zhou, H., Deeb, N., Evock-Clover, C.M., Ashwell, C.M. \& Lamont, S.J. 2006b. Genome-wide linkage analysis to identify chromosomal regions affecting phenotypic traits in the chicken. II. Body composition. Poultry Science 85: 1712-1721. 
Vol. 16 (2007): 177-187

\section{SELOSTUS}

\section{Munijakanojen painoon vaikuttavat kromosomialueet}

Mervi Honkatukia, Maria Tuiskula-Haavisto ja Johanna Vilkki

MTT Biotekniikka- ja elintarviketutkimus

\begin{abstract}
Aiemmassa koko genomin kattavassa tuotantogeenien kartoituksessa on paikannettu kanan perimästä alueita, jotka vaikuttavat kananmunan laatuun ja munantuotannon määrään. Tätä tutkimusta varten risteytettiin resiprookkisesti eli vastavuoroisesti kaksi erilaista munijakanalinjaa. Koska alkuperäiset kanalinjat poikkesivat toisistaan muun muassa kokonsa puolesta, pystyttiin näin paikantamaan kanan aikuispainoon ja syöntiin vaikuttavia tilastollisesti merkitseviä kromosomialueita. Seuraavassa vaiheessa tutkimusaineistoon sovellettiin tilastollisia menetelmiä, joiden avulla oli mahdollista havaita niin sanottu parent-of-origin-vaikutus. Parent-
\end{abstract}

of-origin-vaikutuksella tarkoitetaan sitä, että geenin alleelilla on erilainen vaikutus sen mukaan, kummalta vanhemmalta se on peritty. Nämä vaikutukset huomioimalla löydettiin uusia syöntikykyyn ja painoon vaikuttavia kromosomialueita. Aineistoa analysoitiin myös kolmen uuden ominaisuuden kannalta, huomioimalla kanan paino 16:n, 20:n ja 24 viikon iässä. Analyysin tuloksena löytyi uusia, eri ikäkausina painoon vaikuttavia alueita kromosomeista 1, 4, 5, 6 ja 13. Tulokset tukevat aiempia tutkimuksia ja korostavat tiettyjen kromosomialueiden merkitystä siipikarjan kasvulle ja painon kehitykselle. 